\title{
Kolej w miejscowym planie zagospodarowania przestrzennego
}

\section{Anna Wieczorek}

\section{STRESZCZENIE}

Chaos, w przepisach prawa i sposobie ich interpretacji, utrudnia sporządzanie miejscowych planów zagospodarowania przestrzennego, które dotyczą:

1. przekształcania na inne cele gruntów będących w dyspozycji kolei, a zbędnych dla jej funkcjonowania, przy jednoczesnym zachowaniu istniejących linii kolejowych;

2. terenów sąsiadujących z koleją.

Na przykładzie wybranego miejscowego planu zagospodarowania przestrzennego i wyroku Wojewódzkiego Sądu Administracyjnego wykazano do jakich absurdów prowadzi istniejący system prawny. Jednym z podstawowych problemów jest używanie trzech pojęć, dotyczących gruntów związanych z koleją. Są to:

1. tereny kolejowe, w rozumieniu rozporządzenia w sprawie ewidencji gruntów i budynków;

2. tereny zamknięte ustalone przez ministra właściwego do spraw transportu, o których mowa $\mathrm{w}$ ustawie o planowaniu i zagospodarowaniu przestrzennym;

3. obszar kolejowy, w rozumieniu ustawy o transporcie kolejowym.

Zasugerowano zmiany przepisów, w tym eliminację przynajmniej jednego w ww. pojecć. Postulowane zmiany prawa powinny ułatwić sporządzanie planów miejscowych, co umożliwi kształtowanie przestrzeni miast i wsi na styku z koleją w sposób, który nie generuje konfliktów.

Słowa kluczowe: obszar kolejowy, tereny kolejowe, tereny zamknięte, miejscowy plan zagospodarowania przestrzennego

\section{Wprowadzenie}

Początek budowy kolei na ziemiach należących obecnie do Polski przypada na czas rozbiorów i zaczyna się w zaborze pruskim. „Pierwszą linię kolejową (...) Wrocław - Oława Brzeg, długości 42 km, oddano do użytku już w 1842 r. (...) Stanowiła ona fragment ważnej linii łączącej Wrocław z Górnym Śląskiem (...) i Berlinem." [Taylor 2007, s. 26].

„W Wielkim Księstwie Krakowskim i Galicji pierwsza linia połączyła Kraków z Mysłowicami na Górnym Śląsku (1847), co świadczyło o motywach gospodarczych jej budowy." [Taylor 2007, s. 31]. Kilka lat później „poprowadzono przez Oświęcim tzw. Kolej Północną Cesarza Ferdynanda (...), która dalej już jako Kolej Galicyjska Karola Ludwika biegła z Krakowa do Bochni, a następnie wzdłuż Pogórza Karpackiego na wschód przez Tarnów i Przemyśl do Lwowa (533 km, 1856-1861)." [Taylor 2007, s. 31].

„Pierwsza linia w Królestwie Polskim, zaprojektowana przez polskich inżynierów i zbudowana rękoma polskich robotników, powstała mniej więcej w tym samym czasie co w po- 
zostałych zaborach (1845-1847). Była to normalnotorowa linia warszawsko-wiedeńska łącząca Warszawę z Zagłębiem Górnośląskim (...). Nazwa linii wynika z faktu, że łącznie ze wspomnianą wyżej Koleją Północną tworzyła bezpośrednie połączenie Warszawy z Wiedniem.” [Taylor 2007, s. 31]. „Linia uwzględniała wszystkie ważniejsze miasta między Warszawą i Zagłębiem Górnośląskim. Przyczyniła się m.in. do rozwoju uprzemysłowionego pasma pruszkowskiego i Żyrardowa.” [Taylor 2007, s. 31]. „Dopiero kilkanaście lat później (1862) powstała, szeroko- i od początku dwutorowa, linia warszawsko-petersburska, ignorująca istniejącą sieć osadniczą a będąca pierwszym połączeniem Królestwa Polskiego z Cesarstwem Rosyjskim." [Taylor 2007, s. 32]. Drugie połączenie Królestwa z Rosją to szerokotorowa linia Warszawa - Siedlce - Brześć [Taylor 2007, s. 32].

„Na obecny układ sieci kolejowej złożyło się zatem kilka czynników, przede wszystkim opisane wyżej uwarunkowania historyczne. Ponad 3/4 długości sieci powstało bowiem w okresie zaborów, a tylko reszta w niepodległej Polsce. Nie bez znaczenia jest tutaj także fakt zmiany terytorium kraju po II wojnie światowej i wynikająca z tego konieczność dostosowania sieci do nowych granic państwa i kierunków przewozowych." [Taylor 2007, s. 84].

Kolej miała i nadal ma kluczowy wpływ na funkcjonowanie sąsiadujących z nią terenów, przesądza o ich rozwoju gospodarczym i przestrzennej strukturze jednostek osadniczych, rzutuje na jakość życia mieszkańców. „Przyjmuje się, że jednym z dominujących czynników determinujących rozwój obszarów gospodarczo zacofanych był rozkwit kolejnictwa. Osady wiejskie i miasta, które zrezygnowały z uzgodnienia trasy przebiegu budowanej linii kolejowej, na całe stulecie bezpowrotnie straciły szanse zdynamizowania swojego rozwoju." [Liszaj, Kastelik 2011, s. 6].

Likwidacja kolei, czy zaprzestanie kursowania na danej trasie pociągów pasażerskich ma skutki negatywne. „Zamknięcia linii w ruchu osobowym powodują zazwyczaj dotkliwe następstwa dla społeczności lokalnych. Szczególnie bolesne są skutki zaprzestania kolejowych przewozów pasażerskich w przypadku niewielkich miasteczek i wsi, pozbawionych innych rodzajów transportu.” [Taylor 2007, s. 165]. „Często zamknięcie lokalnego połączenia kolejowego oznacza brak dostępu mieszkańców do obecnych i potencjalnych miejsc zatrudnienia, kształcenia, opieki lekarskiej, zakupów, rozrywki i wielu innych celów." [Taylor 2007, s. 10].

Dworce kolejowe miały i mają istotne znaczenie dla kształtowania przestrzeni miast, a przystanki kolejowe rzutują na rozwój wsi. „Bywało (...), że usytuowany na peryferiach miasta dworzec wymuszał przesunięcie centrum w stronę kolei. Zdarzało się również, że wybudowanie dworca i linii kolejowej w małej osadzie doprowadziło do powstania dużego miasta, którego centrum był dworzec. Przykładem takiego miasta jest Sosnowiec." [Liszaj, Kastelik 2011, s. 7]. Położenie dworców kolejowych wpływało i wpływa na transport publiczny wewnątrz miast. Przykładowo, w 1867 r. w Warszawie „zostaje uruchomiona pierwsza miejska kolej szynowa - łącząca dworzec Drogi Żelaznej Warszawsko-Wiedeńskiej z dworcami Petersburskim (ob. Wileński) i Terespolskim (ob. Wschodni)" [Janczewski 1971, s. 22-23].

Na podstawie wyglądu dworca, przyjezdny wyrabia sobie zdanie o mieście. „Projektantom kolei oraz władzom miasta zależało, by gmach dworca był wizytówką miasta, dlatego 
budynki dworcowe projektowali najbardziej uznani i cenieni architekci." [Liszaj, Kastelik 2011, s. 7-8]. Obecnie, w dużych miastach dworce są niejednokrotnie częścią kompleksów usługowych (handel, gastronomia). Tak jest w np. w Warszawie, Katowicach i Krakowie.

Kolej dysponuje gruntami, położonymi w centrach miast. Część z tych gruntów jest zbędna dla funkcjonowania transportu kolejowego i powinna służyć innym celom. Likwidacji ulegają również całe linie kolejowe. Temu zagadnieniu poświecono sporo miejsca w monografii Z. Taylora pt. Rozwój i regres sieci kolejowej w Polsce - omówiono przyczyny likwidacji oraz sposoby wykorzystywania terenów po zlikwidowanych liniach kolejowych [Taylor 2007, pkt 5.1.4.].

Do zachowania optymalnych relacji między koleją a pozostałymi częściami miast powinno, prócz zdrowego rozsądku, służyć prawo, w tym akty prawa miejscowego, jakimi są miejscowe plany zagospodarowania przestrzennego. Od 2010 r. ustawa o planowaniu i zagospodarowaniu przestrzennym (upzp) zezwala na uchwalanie planów miejscowych dla terenów zamkniętych ustalonych przez ministra właściwego do spraw transportu. Są to głównie tereny w dyspozycji kolei. Niestety, wraz z nowelizacją ww. ustawy, nie dokonano zmian w innych aktach prawa. Do kluczowych problemów należy zaliczyć istnienie w systemie prawnym trzech pojęć, dotyczących gruntów związanych z koleją. Są to:

1. tereny kolejowe, w rozumieniu rozporządzenia w sprawie ewidencji gruntów i budynków (rozp. eg);

2. tereny zamknięte ustalone przez ministra właściwego do spraw transportu, o których mowa w ustawie o planowaniu i zagospodarowaniu przestrzennym, w związku z ustawą Prawo geodezyjne i kartograficzne (ugk);

3. obszar kolejowy, w rozumieniu ustawy o transporcie kolejowym (utk).

Ustawie o planowaniu i zagospodarowaniu przestrzennym, w tym miejscowym planom zagospodarowania przestrzennego poświęconych jest wiele publikacji. Wystarczy wymienić tylko prace pod redakcją Zygmunta Niewiadomskiego, w tym Planowanie i zagospodarowanie przestrzenne. Komentarz, które doczekało się aż 11 wydań. Badania dotyczące kolejnictwa były i są prowadzone na wyższych uczelniach, np. na Politechnice Warszawskiej (Andrzej Chudzikiewicz) i w instytutach naukowych, np. w Instytucie Geografii i Przestrzennego Zagospodarowania PAN (Teofil Lijewski, Zbigniew Taylor, Ariel Ciechański). Dzięki temu kolej doczekała się bogatej literatury. Nie znaleziono jednak publikacji dotyczącej:

1. wzajemnych relacji między terenami kolejowymi, terenami zamkniętymi i obszarem kolejowym;

2. relacji między ww. terenami a planami miejscowymi. 


\section{Tereny kolejowe, tereny zamknięte, obszar kolejowy}

\section{Tereny kolejowe}

„Do terenów kolejowych zalicza się grunty zajęte pod budowle i inne urządzenia przeznaczone do wykonywania i obsługi ruchu kolejowego: torowiska kolejowe, stacje, rampy, magazyny, bocznice kolejowe itp.” [Załącznik nr 6 do rozp.eg pt. „Zaliczanie gruntów do poszczególnych użytków gruntowych"].

Ewidencja gruntów i budynków (kataster nieruchomości) to „system informacyjny zapewniający gromadzenie, aktualizację oraz udostępnianie, w sposób jednolity dla kraju, informacji o gruntach, budynkach i lokalach, ich właścicielach oraz o innych podmiotach władających lub gospodarujących tymi gruntami, budynkami lub lokalami” [art. 2 pkt 8 ugk].

Wykazane w ewidencji użytki gruntowe dzielą się na następujące grupy:

1. grunty rolne;

2. grunty leśne;

3. grunty zabudowane i zurbanizowane;

4. użytki ekologiczne,

5. grunty pod wodami;

6. tereny różne [ $§ 67$ rozp.eg].

Tereny kolejowe są częścią gruntów zabudowanych i zurbanizowanych [§ 68 rozp.eg].

Przepisy ustawy Prawo geodezyjne i kartograficzne świadczą dobitnie o znaczeniu ewidencji gruntów i budynków dla funkcjonowania Państwa. „Podstawę planowania gospodarczego, planowania przestrzennego, wymiaru podatków i świadczeń, oznaczania nieruchomości w księgach wieczystych, statystyki publicznej, gospodarki nieruchomościami oraz ewidencji gospodarstw rolnych stanowią dane zawarte w ewidencji gruntów i budynków." [art. 21 ust.1 ugk].

Tereny kolejowe są oznaczone na mapach zasadniczych symbolem Tk. Mapa zasadnicza, to „wielkoskalowe opracowanie kartograficzne, zawierające informacje o przestrzennym usytuowaniu: punktów osnowy geodezyjnej, działek ewidencyjnych, budynków, konturów użytków gruntowych, konturów klasyfikacyjnych, sieci uzbrojenia terenu, budowli i urządzeń budowlanych oraz innych obiektów topograficznych, a także wybrane informacje opisowe dotyczące tych obiektów" [art. 2 pkt 7 ugk].

Ewidencja gruntów i budynków oraz mapy zasadnicze wchodzą w skład państwowego zasobu geodezyjnego i kartograficznego. Państwowy zasób geodezyjny i kartograficzny „to zbiory danych prowadzone (...) przez organy Służby Geodezyjnej i Kartograficznej, utworzone na podstawie tych zbiorów danych opracowania kartograficzne, rejestry, wykazy i zestawienia, dokumentacja zawierająca wyniki prac geodezyjnych lub prac kartograficznych lub dokumenty utworzone w wyniku tych prac, a także zobrazowania lotnicze i satelitarne" [art. 2 pkt 10 ugk].

„Ewidencję gruntów i budynków oraz gleboznawczą klasyfikację gruntów prowadzą starostowie." [art. 22 ust.1 ugk]. 
Nie znaleziono przepisów, które nakazują zachowanie odpowiedniej odległości obiektów budowlanych niezwiązanych z koleją albo drzew od granic ww. terenów.

\section{Tereny zamknięte}

Tereny zamknięte to „tereny o charakterze zastrzeżonym ze względu na obronność i bezpieczeństwo państwa, określone przez właściwych ministrów i kierowników urzędów centralnych" [art. 2 pkt 9 ugk]. To przede wszystkim tereny ustalone przez ministra właściwego do spraw obrony narodowej.

„Dokumentacja geodezyjna określająca przebieg granic i powierzchnię terenu zamkniętego przekazywana jest przez organy wydające decyzje o zamknięciu terenu właściwym terytorialnie starostom.”[art. 4 ust. 2a ugk]. „Dla terenów zamkniętych, zamiast mapy zasadniczej, sporządza się odrębne mapy zawierające w swojej treści również sieć podziemnego uzbrojenia terenu. Sporządzanie i aktualizowanie tych map oraz ustalanie granic terenów zamkniętych należy do właściwych ministrów i kierowników urzędów centralnych." [art. 4 ust. 2 ugk]. „Właściwi ministrowie i kierownicy urzędów centralnych zawiadamiają Głównego Geodetę Kraju o ustaleniu terenu zamkniętego oraz podają klauzulę tajności informacji dotyczących obiektów znajdujących się na tym terenie" [art. 4 ust. 2b ugk]. Na mapach zasadniczych tereny zamknięte to swego rodzaju biała plama - często widać jedynie ich granice.

Ustawia o planowaniu i zagospodarowaniu przestrzennym odsyła do definicji terenów zamkniętych zawartej w ustawie Prawo geodezyjne i kartograficzne [art. 2 pkt 11 upzp] oraz dodatkowo wprowadza pojęcie tereny zamknięte ustalone przez ministra właściwego do spraw transportu [art. 4 ust. 4 upzp].

Nie znaleziono przepisów, które wprost nakazują zachowanie odpowiedniej odległości np. drzew albo obiektów budowlanych niezwiązanych $\mathrm{z}$ funkcjonowaniem terenów zamkniętych od granic ww. terenów. Ustawa o planowaniu i zagospodarowaniu przestrzennym stanowi jedynie, że w miejscowym planie zagospodarowania przestrzennego wokół terenów zamkniętych wyznacza się ich strefy ochronne, w których „ustala się ograniczenia w zagospodarowaniu i korzystaniu z terenów, w tym zakaz zabudowy" [art. 4 ust. 3 upzp]. Powyższy przepis nie precyzuje, czy wielkość ww. strefy wynika z decyzji, na podstawie której ustalono dany teren zamknięty, czy to sporządzający plan miejscowy decyduje o konieczności jej wyznaczenia i ustala wymiary.

\section{Obszar kolejowy}

Obszar kolejowy, to „powierzchnia gruntu określona działkami ewidencyjnymi, na której znajduje się droga kolejowa, budynki, budowle i urządzenia przeznaczone do zarządzania, eksploatacji i utrzymania linii kolejowej oraz przewozu osób i rzeczy" [art. 4 pkt 8 utk]. 
Droga kolejowa, to „tor kolejowy albo tory kolejowe wraz z elementami wymienionymi w pkt 2-12 załącznika nr 1 do ustawy, o ile są z nimi funkcjonalnie połączone, niezależnie od tego, czy zarządza nimi ten sam podmiot" [art. 4 pkt 1a utk].

Linia kolejowa, to „wyznaczona przez zarządcę infrastruktury droga kolejowa przystosowana do prowadzenia ruchu pociągów" [art. 4 pkt 2 utk].

Dworzec kolejowy, to „obiekt budowlany lub zespół obiektów budowlanych, w którym znajdują się pomieszczenia przeznaczone do obsługi podróżnych korzystających z transportu kolejowego, położony przy linii kolejowej” [art. 4 pkt 8a utk].

Infrastruktura kolejowa, to „elementy określone w załączniku nr 1 do ustawy” [art. 4 pkt 1 utk]. „W skład infrastruktury kolejowej wchodzą następujące elementy, pod warunkiem że tworzą część linii kolejowej, bocznicy kolejowej lub innej drogi kolejowej, lub są przeznaczone do zarządzania nimi, obsługi przewozu osób lub rzeczy, lub ich utrzymania:

1. tory kolejowe, w tym rozjazdy i skrzyżowania torów, wchodzące w ich skład szyny, szyny żłobkowe, kierownice, odbojnice, prowadnice, zwrotnice, krzyżownice i inne elementy rozjazdów, podkłady kolejowe i przytwierdzenia, drobne elementy nawierzchni kolejowej, podsypka w tym tłuczeń i piasek;

2. obrotnice i przesuwnice;

3. podtorze, w szczególności nasypy i przekopy, systemy kanałów i rowów odwadniających, rowy murowane, ściany osłonowe, roślinność posadzona w celu ochrony skarp;

4. obiekty inżynieryjne: mosty, wiadukty, przepusty i inne konstrukcje mostowe, tunele, przejścia nad i pod torami, mury oporowe i umocnienia skarp;

5. nastawnie, urządzenia sterowania ruchem kolejowym, w tym urządzenia zabezpieczające, sygnalizacyjne i łącznościowe na szlaku, w stacjach i stacjach rozrządowych, urządzenia służące do wytwarzania, przetwarzania i dystrybucji prądu elektrycznego do celów sygnalizacji i łączności; budynki, w których takie urządzenia lub instalacje się znajdują przytorowe urządzenia kontroli bezpiecznej jazdy pociągów i wykrywania stanów awaryjnych w przejeżdżającym taborze; hamulce torowe; urządzenia do ogrzewania rozjazdów;

6. perony wraz z infrastrukturą umożliwiającą dotarcie do nich pasażerom, pieszo lub pojazdem, z drogi publicznej lub dworca kolejowego;

7. rampy towarowe, $\mathrm{w}$ tym $\mathrm{w}$ terminalach towarowych, wraz $\mathrm{z}$ drogami dowozu i odwozu towarów do dróg publicznych;

8. drogi technologiczne i przejścia wzdłuż torów, mury ogradzające, żywopłoty, ogrodzenia, pasy przeciwpożarowe, zasłony odśnieżne;

9. przejazdy kolejowo-drogowe i przejścia w poziomie szyn, w tym urządzenia i systemy służące zapewnieniu bezpieczeństwa ruchu drogowego i pieszego;

10. systemy oświetleniowe do celów ruchu kolejowego i bezpieczeństwa;

11. urządzenia przetwarzania i rozdziału energii elektrycznej na potrzeby zasilania trakcyjnego: podstacje, kable zasilające pomiędzy podstacjami i przewodami jezdnymi, sieć trakcyjna wraz z konstrukcjami wsporczymi, trzecia szyna z konstrukcjami wsporczymi;

12. grunty, oznaczone jako działki ewidencyjne, na których znajdują się elementy wymienione w pkt 1-11.” [Załącznik nr 1 do utk pt. „Wykaz elementów infrastruktury kolejowej”]. 
Sumując, w skład obszaru kolejowego wchodzą:

1. wymieniona w punkcie 12 załącznika nr 1 do ustawy o transporcie kolejowym „powierzchnia gruntu określona działkami ewidencyjnymi, na której znajduje się droga kolejowa", czyli:

- tor kolejowy albo tory kolejowe, wymienione w punkcie 1 ww. załącznika nr 1,

- $\quad$ elementy wymienione w punktach 2-11 ww. załącznika nr 1;

2. budynki, budowle i urządzenia przeznaczone do zarządzania, eksploatacji i utrzymania linii kolejowej;

3. budynki, budowle i urządzenia przeznaczone do przewozu osób i rzeczy, zapewne dworce kolejowe, przy czym ustawa o transporcie kolejowym stanowi jedynie, że dworzec kolejowy jest położony przy linii kolejowej.

Relacje między obszarem kolejowym a innymi obiektami, kształtującymi przestrzeń miast i wsi, determinują przepisy ustawy o transporcie kolejowym:

1. usytuowanie budowli, budynków, drzew i krzewów oraz wykonywanie robót ziemnych nie może stanowić zagrożenia bezpieczeństwa ruchu kolejowego [art. 53 ust. 1 utk];

2. budowle i budynki „mogą być usytuowane w odległości nie mniejszej niż $10 \mathrm{~m}$ od granicy obszaru kolejowego, z tym, że odległość ta od osi skrajnego toru nie może być mniejsza niż 20 m" [art. 53 ust. 2 utk];

3. powyższe nie dotyczy „budynków i budowli przeznaczonych do prowadzenia ruchu kolejowego i utrzymania linii kolejowej oraz do obsługi przewozu osób i rzeczy" [art. 53 ust. 4 utk].

Porównując definicję pojęcia obszar kolejowy oraz ww. przepis art. 53 ust. 4 ustawy o transporcie kolejowym można dojść do wniosku, że istnieją:

1. położone na obszarze kolejowym - „budynki, budowle i urządzenia przeznaczone do zarządzania, eksploatacji i utrzymania linii kolejowej oraz przewozu osób i rzeczy" [art. 4 pkt 8 utk];

2. położone poza obszarem kolejowym - budynki i budowle przeznaczone „do prowadzenia ruchu kolejowego i utrzymania linii kolejowej oraz do obsługi przewozu osób i rzeczy" [art. 53 ust. 4 utk], których lokalizacji nie dotyczą odległości 10 m od granicy obszaru kolejowego i $20 \mathrm{~m}$ od osi skrajnego toru.

Ustawodawca nie wyjaśnia czym się różnią ww. budynki i budowle położone na obszarze kolejowym od ww. budynków i budowli położonych poza tym obszarem. Z definicji pojęcia dworzec kolejowy wynika, że może on być położony na obszarze kolejowym albo poza tym obszarem

W szczególnie uzasadnionych przypadkach, ustawa o transporcie kolejowym dopuszcza odstępstwa od określonych odległości 10 m i 20 m, przy czym nie może to powodować zagrożenia życia ludzi oraz bezpieczeństwa ruchu kolejowego [art. 57 ust. 1 i art. 57a ust. 1 utk].

Zgody na odstępstwa, po uzyskaniu opinii właściwego zarządcy:

1. udziela właściwy organ administracji architektoniczno-budowlanej, w przypadku usytuowania budynków i budowli oraz wykonywania robót ziemnych [art. 57 ust. 2 utk];

2. udziela starosta, w przypadku usytuowania drzew i krzewów [art. 57a ust. 2 utk]. 
Jeśli chce się uzyskać powyższe odstępstwa, trzeba ustalić:

1. granice obszaru kolejowego;

2. położenie osi skrajnego toru;

3. kim jest właściwy zarządca;

4. kim jest właściwy organ administracji architektoniczno-budowlanej.

Na żadnej z map pochodzących z państwowego zasobu geodezyjnego i kartograficznego, w tym na mapach zasadniczych, na których wykonuje się rysunki planów miejscowych i projekty budowlane, nie ma granic obszaru/ów kolejowych. Nie znaleziono żadnej decyzji, ani innego dokumentu, który wyznacza numery działek ewidencyjnych, traktowanych jako obszar kolejowy. Na podstawie map pochodzących z państwowego zasobu geodezyjnego i kartograficznego można określić jedynie położenie osi skrajnego toru.

Na brak granic obszaru kolejowego i wynikające z tego problemy zwróciła uwagę w 2019 r. pani poseł Małgorzata Pępek w interpelacji nr 29420, skierowanej do Ministra Infrastruktury oraz do ówczesnego Ministra Inwestycji i Rozwoju (ministerstwo nie istnieje). W odpowiedziach na powyższą interpelację obydwaj Ministrowie potwierdzają brak ww. granic na mapach zasadniczych.

Ówczesny Minister Inwestycji i Rozwoju (MIR) w piśmie z dnia 08. 03. 2019 r.:

1. stwierdził, że wykaz obiektów stanowiących treść mapy zasadniczej nie zawiera obiektu obszar kolejowy [MIR, s. 4];

2. napisał, że pojęcia „obszar kolejowy”, "teren kolejowy” i "teren zamknięty” nie są pojęciami tożsamymi i nie mogą być zamiennie stosowane dla realizacji normy zawartej w art. 53 ust. 2 utk [MIR, s. 5], czyli do ustalania odległości budynków i budowli od obszaru kolejowego.

Minister Infrastruktury (MI) w piśmie z dnia 11.03.2019, w sposób pośredni, wskazuje na brak granic obszaru kolejowego na mapach zasadniczych. "Na mapach zasadniczych/ katastralnych (ewidencyjnych) jest ukazane uzbrojenie terenu naziemne i podziemne, co pozwala stwierdzić, na których działkach znajdują się droga kolejowa, budynki, budowle i urządzenia przeznaczone do zarządzania, eksploatacji i utrzymania linii kolejowej oraz przewozu osób i rzeczy, a tym samym określić granice obszaru kolejowego."[MI, s. 1]. Zalecając analizę map zasadniczych i katastralnych Minister Infrastruktury:

1. zapomniał wskazać, kto jest upoważniony do przeprowadzenia takich analiz i określania czy np. dany wodociąg lub światłowód służy wyłącznie kolei;

2. zapomniał o tym, że część obiektów służących kolei jest objętych klauzulą tajności i nie ma ich na ww. mapach.

Ustalenie, kim jest właściwy zarządca wymaga szczegółowego przestudiowania systemu zarządzania koleją. Ustawa o komercjalizacji i restrukturyzacji przedsiębiorstwa państwowego „Polskie Koleje Państwowe” (ukrPKP) doprowadziła do: :

1. komercjalizacji działającego od 1995 r. przedsiębiorstwa państwowego „Polskie Koleje Państwowe” , zwanego „PKP”; [art. 1 pkt 1 ukrPKP];

2. „przekształcenia PKP w spółkę akcyjna, w której Skarb Państwa jest jedynym akcjonariuszem" [art. 2 ust. 1 ukrPKP]. 
Na podstawie ww. ustawy „w 2001 r. wydzielono 24 spółki zależne tworzące Grupę PKP” [Taylor 2007, s. 184]. Utworzono, m.in., „spółkę akcyjną do prowadzenia działalności w zakresie zarządzania liniami kolejowymi, działającą pod firmą „PKP Polskie Linie Kolejowe Spółka Akcyjna”, zwaną dalej „PLK SA” [art. 15 ust. 1 ukrPKP]. „PLK SA zarządza liniami kolejowymi oraz pozostałą infrastrukturą kolejową (...), z wyłączeniem budynków i budowli przeznaczonych do obsługi przewozu osób i rzeczy wraz z zajętymi pod nie gruntami." [art. 15 ust. 4 a ukrPKP].

Z powyższego wynika, że zarządcą tej części obszaru kolejowego, na której znajduje się droga kolejowa, będąca linią kolejową (czyli przede wszystkim tory kolejowe), jest PLK SA. Może się również zdarzyć, że zarządcą jest samorząd terytorialny albo przedsiębiorca. „Linie kolejowe niebędące liniami o znaczeniu państwowym mogą być (...) przekazywane nieodpłatnie na własność jednostce samorządu terytorialnego (...) w celu wykonywania przewozów kolejowych" [art. 18a ust.1 ukrPKP] lub sprzedawane przedsiębiorcom [art. $18 \mathrm{~b}$ ukrPKP]. PLK SA, samorząd terytorialny albo przedsiębiorcy będą zapewne również zarządcami budynków, budowli i urządzeń przeznaczonych do zarządzania, eksploatacji i utrzymania linii kolejowej.

Natomiast zarządcą budynków, budowli i urządzeń przeznaczonych do przewozu osób i rzeczy, np. dworców kolejowych może być ktoś inny, np. samorząd terytorialny. „PKP SA (...) może przenieść $\mathrm{w}$ drodze umowy na jednostkę samorządu terytorialnego prawo własności albo prawo użytkowania wieczystego nieruchomości wraz z usytuowanymi na niej budynkami dworców kolejowych w granicach niezbędnych do prawidłowego z nich korzystania." [art. 18d ust.1 ukrPKP].

Ustawa Prawo budowlane $(\mathrm{uPb})$ stanowi, że organem administracji architektoniczno-budowlanej pierwszej instancji w przytłaczającej większości spraw jest starosta [art. 82 ust. $2 \mathrm{uPb}$. Organem administracji architektoniczno-budowlanej wyższego stopnia w stosunku do starosty jest wojewoda. Wojewoda jest również organem pierwszej instancji w sprawach obiektów i robót budowlanych:

1. na obszarze kolejowym [art. 82 ust. 3 pkt $3 \mathrm{a} \mathrm{uPb}$;

2. na terenach zamkniętych [art. 82 ust. 3 pkt $5 \mathrm{uPb}$ ].

W świetle powyższych przepisów, uzyskanie odstępstwa dotyczącego lokalizacji budynku, czy budowli (np. drogi) bliżej niż 10 m od granicy obszaru kolejowego można uznać za niewykonalne, a w najlepszym razie - obarczone ogromną uznaniowością. Najpierw trzeba ustalić granice ww. obszaru. Nie znaleziono żadnego przepisu, który upoważnia jakiś organ, czy instytucję do dokonania tej czynności. Sugerowana przez Ministra Infrastruktury analiza map jest wysoce kontrowersyjna. Nie wiadomo, kto ma ją wykonać. Zarządcy, bo będzie ich zapewne kilku, mogą mieć różne zdanie na temat terenu, którym zarządzają.

Mniej uznaniowości będzie przy uzyskiwaniu odstępstwa dotyczącego lokalizacji budynków i budowli bliżej niż $20 \mathrm{~m}$ od osi skrajnego toru. Oś toru daje się wyznaczyć, np. na podstawie map odrębnych, a podmiotem zarządzającym torami będzie albo PLK SA, albo samorząd terytorialny, albo przedsiębiorca. Na ww. odstępstwo musi wyrazić zgodę właściwy organ administracji architektoniczno-budowlanej. W większości przepadków będzie to 
starosta. Może się jednak okazać, że budynek, którego odstępstwo ma dotyczyć, jest projektowany na terenie zamkniętym. W takiej sytuacji musi wyrazić zgodę wojewoda.

Powyższe rozważania dotyczą uzyskiwania odstępstw przy wykonywaniu projektu budowlanego. Inaczej wygląda to przy sporządzaniu planów miejscowych.

\section{Kolej w planie miejscowym}

\section{Kolej, a obowiązek sporządzenia miejscowego planu zagospodarowania przestrzennego}

Miejscowy plan zagospodarowania przestrzennego, zwany w skrócie planem miejscowym, jest podstawowym narzędziem kształtowania przestrzeni w Polsce, aktem prawa miejscowego w rozumieniu przepisu art. 14 ust. 8 ustawy o planowaniu i zagospodarowaniu przestrzennym i źródłem prawa w rozumieniu art. 87 ust. 2 związku z art. 94 Konstytucji Rzeczypospolitej Polskiej. Projekt planu miejscowego sporządza wójt, burmistrz albo prezydent miasta, zgodnie z ustawą o planowaniu i zagospodarowaniu przestrzennym oraz z przepisami odrębnymi [art. 15 ust. 1 upzp] a uchwala rada gminy [art. 20 ust. 1 upzp]. Uchwalony plan miejscowy wójt, burmistrz albo prezydent miasta przedstawia wojewodzie - organowi nadzoru „wraz z załącznikami oraz dokumentacją prac planistycznych w celu oceny ich zgodności z przepisami prawnymi” [art. 20 ust. 2 upzp].

Plan miejscowy sporządza się obowiązkowo, jeżeli wymagają tego przepisy odrębne [art. 14 ust. 7 upzp]. Nie znaleziono przepisu, który nakazuje sporządzenie planu miejscowego dla terenów, na których istnieją lub planuje się lokalizację obiektów służących transportowi kolejowemu, czy dla gruntów sąsiadujących z koleją.

„Planu miejscowego nie sporządza się dla terenów zamkniętych, z wyłączeniem terenów zamkniętych ustalanych przez ministra właściwego do spraw transportu” [art. 14 ust. 6 upzp].

„W odniesieniu do terenów zamkniętych w miejscowym planie zagospodarowania przestrzennego ustala się tylko granice tych terenów oraz granice ich stref ochronnych. W strefach ochronnych ustala się ograniczenia w zagospodarowaniu i korzystaniu z terenów, w tym zakaz zabudowy.” [art. 4 ust. 3 upzp]. Powyższego przepisu „nie stosuje się do terenów zamkniętych ustalanych przez ministra właściwego do spraw transportu" [art. 4 ust. 4 upzp].

Sumując, dla terenów zamkniętych ustalanych przez ministra właściwego do spraw transportu:

1. można, ale nie trzeba sporządzać planów miejscowych;

2. jeśli sporządza się plany miejscowe, to obowiązują zasady określone ustawą o planowaniu i zagospodarowaniu przestrzennym, takie same jak dla innych terenów;

3. nie wyznacza się granic stref ochronnych. 


\section{Ustalenia planu miejscowego - przeznaczenie terenu}

Plan miejscowy sporządza się w celu „ustalenia przeznaczenia terenów, w tym dla inwestycji celu publicznego, oraz określenia sposobów ich zagospodarowania i zabudowy" [art. 14 ust. 1 upzp]. Zakres stanowienia planu jest bardzo obszerny. W sposób szczegółowy ustalają go przepisy art. 15 ustawy o planowaniu i zagospodarowaniu przestrzennym. W dużym uproszczeniu - w planie miejscowym określa się obowiązkowo:

1. przeznaczenie terenów, czyli czy na danym terenie wolno coś budować, a jeżeli wolno to jakie obiekty mogą powstać;

2. zasady kształtowania zabudowy.

Ustawa o planowaniu i zagospodarowaniu przestrzennym nie definiuje pojęcia przeznaczenie terenu. Rozporządzenie w sprawie wymaganego zakresu projektu miejscowego planu zagospodarowania przestrzennego (rozp. mpzp) ogranicza się do stwierdzenia, że:

1. „ustalenia dotyczące przeznaczenia terenów powinny zawierać określenie przeznaczenia poszczególnych terenów lub zasad ich zagospodarowania, a także symbol literowy i numer wyróżniający go spośród innych terenów" [§ 4. pkt 1 rozp. mpzp];

2. „oznaczenia graficzne i literowe dotyczące przeznaczenia terenów, które należy stosować na projekcie rysunku planu miejscowego, określa załącznik nr 1 do rozporządzenia" [§ 9 ust. 1 rozp. mpzp].

3. „dopuszcza się stosowanie na projekcie rysunku planu miejscowego uzupełniających i mieszanych oznaczeń barwnych i jednobarwnych oraz literowych i cyfrowych" [§ 9 ust. 4 rozp. mpzp].

Załącznik nr 1 do ww. rozporządzenia zawiera listę nazw terenów i ich oznaczeń, np.:

- tereny zabudowy usługowej - symbol U, kolor czerwony,

- tereny dróg publicznych - symbol KD, kolor biały,

- tereny komunikacji wodnej - symbol KW, kolor ciemnoniebieski.

Na powyższej liście nie ma symboli i kolorów, którymi mają być oznaczone na rysunku planu tereny związane z koleją.

Ustawa o planowaniu i zagospodarowaniu przestrzennym nakazuje jedynie określić „,zasady modernizacji, rozbudowy i budowy systemów komunikacji i infrastruktury technicznej" [art. 15 ust. 2 pkt 10 upzp]. Przepis wykonawczy wymaga określenia powiązań układu komunikacyjnego na obszarze objętym planem miejscowym z układem zewnętrznym [§ 4 pkt 9 rozp. mpzp]. W zależności od potrzeb, w planie miejscowym, określa się granice inwestycji celu publicznego [15 ust. 3 pkt 4 a i pkt 4 b upzp].

Pozostaje bezspornym, że linie kolejowe są celami publicznymi w rozumieniu ustawy o gospodarce nieruchomościami [art. 6 pkt 1a ugn] oraz inwestycjami celu publicznego w rozumieniu ustawy o planowaniu i zagospodarowaniu przestrzennym. Wydaje się, że celami publicznymi są również inne obiekty wymienione w definicji obszaru kolejowego, w tym dworce kolejowe.

Wymaga podkreślenia, że ani ustawa o planowaniu i zagospodarowaniu przestrzennym, ani przepisy odrębne nie zabraniają przeznaczania $\mathrm{w}$ planie miejscowym na cele inne niż 
związane z koleją obszaru kolejowego, terenów kolejowych oraz terenów zamkniętych ustalanych przez ministra właściwego do spraw transportu. Nie ma żadnego przepisu, który w trakcie sporządzania planu miejscowego nakazuje uzyskanie zgody właściwego w sprawie orgau (np. minister właściwy do spraw transportu) na zmianę przeznaczenia obszaru kolejowego, terenów kolejowych czy ww. terenów zamkniętych, np. na drogę czy obiekt, w którym wykonuje się usługi. Ustawa o planowaniu i zagospodarowaniu przestrzennym, ustawa o transporcie kolejowym oraz ustawa o komercjalizacji i restrukturyzacji przedsiębiorstwa państwowego „Polskie Koleje Państwowe” nie wskazują żadnych organów właściwych do uzgadniania projektów planów miejscowych dotyczących kolei lub terenów z nią sąsiadujących. Organy administracji architektoniczno-budowlanej, a tym bardziej zarządcy, o których mowa w przepisie art. 57 ust. 2 ustawy o transporcie kolejowym, nie są organami właściwymi do opiniowania i uzgadniania miejscowych planów zagospodarowania przestrzennego.

Ustawa o komercjalizacji i restrukturyzacji przedsiębiorstwa państwowego „Polskie Koleje Państwowe" stanowi, że:

1. mienie PKP SA „może być przekazane nieodpłatnie, w drodze umowy, na własność jednostkom samorządu terytorialnego, na cele związane $\mathrm{z}$ inwestycjami infrastrukturalnymi służącymi wykonywaniu zadań własnych tych jednostek w dziedzinie transportu" [art. 39 ust. 3 ukrPKP];

2. „PKP SA może przekazać, w drodze umowy, nieodpłatnie jednostce samorządu terytorialnego, spółdzielni mieszkaniowej albo wspólnocie mieszkaniowej urządzenia wchodzące w skład infrastruktury technicznej wraz z niezbędnymi do korzystania $\mathrm{z}$ nich gruntami." [art. 47 ukrPKP].

Nie ma przeciwwskazań, aby grunty i obiekty budowlane, z których kolej przestała korzystać, przeznaczać w planach miejscowych na inne cele.

\section{Ustalenia planu miejscowego - rysunek planu}

Rysunek miejscowego planu zagospodarowania przestrzennego sporządza się najczęściej w skali 1:1000 (dopuszcza się stosowanie map w skali 1:500 lub 1:2000) „z wykorzystaniem urzędowych kopii map zasadniczych albo w przypadku ich braku map katastralnych, gromadzonych w państwowym zasobie geodezyjnym i kartograficznym" [art. 16 ust. 1 upzp].

Na mapach zasadniczych i katastralnych, na których wykonuje się rysunek planu miejscowego, są wyznaczone jedynie tereny kolejowe oznaczone symbolem Tk. Jak już napisano - nie ma na nich obszaru kolejowego. Nie ma również innych dokumentów ustalających położenie tego obszaru. Nie sposób wiec wyznaczyć odległość 10 m od granicy obszaru kolejowego.

Odpowiedzialny za planowanie przestrzenne do jesieni 2019 r. Minister Inwestycji i Rozwoju zasugerował, że działki ewidencyjne wchodzące „w skład istniejącego obszaru kolejowego dla obszaru planu miejscowego winien wskazać zarządca infrastruktury kolejowej po 
otrzymaniu na piśmie zawiadomienia o podjęciu uchwały przez radę gminy o przystąpieniu do sporządzenia planu miejscowego (art. 17 pkt 2 upzp)” [MIR s. 5]. Tyle, że z przepisu art. 17 pkt 2 ustawy o planowaniu i zagospodarowaniu przestrzennym i z przepisów odrębnych nie wynika obowiązek powiadamiania zarządcy czy zarządców infrastruktury kolejowej. Oczywiście sporządzający plan miejscowy może prowadzić korespondencję z każdym, ale pisma zarządcy mają jedynie charakter informacyjny i nie rodzą skutków prawnych. Wskazane przez zarządcę działki ewidencyjne moga ale nie muszą być traktowane jako obszar kolejowy w rozumieniu ustawy o transporcie kolejowym, np. w sporze sądowym.

Minister Inwestycji i Rozwoju zauważył również, że „z przepisów regulujących zarówno treść mapy zasadniczej, z wykorzystaniem której sporządzany jest miejscowy plan zagospodarowania przestrzennego (art.16 ust. 1 upzp), jak i określających zakres planu miejscowego nie wynika obowiązek ujęcia w treści tych opracowań granicy obszaru kolejowego w rozumieniu przepisów utk. Ustalenia planu miejscowego nie konkretyzują też usytuowania projektowanych budynków. Wymóg odległościowy od granicy obszaru kolejowego powinien zostać uwzględniony i wzięty pod uwagę przy określeniu w projekcie planu miejscowego przebiegu linii zabudowy, o której mowa w art. 15 ust. 2 pkt 6 upzp, na terenach sąsiadujących z istniejącymi i projektowanymi terenami komunikacji kolejowej" [MIR s. 5-6].

Sumując, odpowiedzialny za planowanie przestrzenne do jesieni 2019 r. Minister Inwestycji i Rozwoju uważał, że:

1. tereny kolejowe, teren zamknięty ustalany przez ministra właściwego do spraw transportu i obszar kolejowy to nie to samo;

2. w planach miejscowych nie ma obowiązku określania granic obszaru kolejowego;

3. w planach miejscowych można zaprojektować „tereny komunikacji kolejowej” niezależnie od istniejących terenów komunikacji kolejowej, bez wyjaśniania, co rozumie pod tym pojęciem.

Na rysunku planu miejscowego należy wyznaczyć granice wszystkich rodzajów terenów zamkniętych [§ 7 pkt 5 rozp.mpzp], przy czym:

1. teren zamknięty ustalany przez ministra właściwego do spraw transportu wolno zmienić na inne cele i tym samym widnieją na nim oznaczenia rysunku planu [art. 4 ust.4 upzp];

2. teren zamknięty ustalany przez inny organ, nie jest oznaczony żadnym z symboli stosowanych przy sporządzaniu planu, ponieważ nie wolno go przeznaczyć na inne cele - jest na nim tylko to, co widać na mapie, na której wykonano rysunek planu.

\section{Skarga organu nadzoru na uchwałę Nr XLV.442.2018 Rady Miasta Mińsk Mazowiecki}

\section{Skarga organu nadzoru i wyrok Wojewódzkiego Sądu Administracyjnego}

W dniu 15 października 2018 r. Rada Miasta Mińsk Mazowiecki przyjęła uchwałą Nr XLV.442.2018 miejscowy plan zagospodarowania przestrzennego miasta Mińsk Mazowiecki (uchwała). Plan dotyczy części miasta, rozdzielonych jedną z najstarszych w Polsce linii ko- 
lejowych Warszawa - Siedlce - Brześć i miał służyć, m.in., przeznaczeniu na drogi publiczne gruntów, z których kolej nie korzysta.

Organ nadzoru, w przysługującym mu terminie 30 dni, nie stwierdził nieważności uchwały, co można uznać za potwierdzenie jej zgodności z prawem. Dopiero w dniu 8 stycznia 2019 r. wystosował do Wojewódzkiego Sądu Administracyjnego skargę na ww. uchwałę. Zarzucił naruszenie przepisów art. 15 ust. 1, art. 15 ust. 2 pkt 7 i 9 oraz art. 28 ust. 1 ustawy o planowaniu i zagospodarowaniu przestrzennym w związku z art. 4 pkt 8, art. 53 ust. 2, art. 57 ustawy o transporcie kolejowym „poprzez dopuszczenie do realizacji obiektów budowlanych innych niż droga kolejowa, budynki, budowle i urządzenia przeznaczone do zarządzania, eksploatacji i utrzymania linii kolejowej oraz przewozu osób i rzeczy w granicach obszaru kolejowego, jak również braku uwzględnienia ograniczeń w zagospodarowaniu i zabudowie w odległości 10 m od granicy obszaru kolejowego" [skarga s. 1]. Organ nadzoru wystąpił o stwierdzenie nieważności zaskarżonej uchwały w zakresie ustaleń dotyczących:

1. terenów oznaczonych symbolami $2 \mathrm{KDD}, 1 \mathrm{KK} / \mathrm{D}$ i $3 \mathrm{KK} / \mathrm{D}$, położonych jego zdaniem w granicach obszaru kolejowego;

2. terenów oznaczonych symbolami 2KK/D i 7KDL, położonych jego zdaniem częściowo w granicach obszaru kolejowego;

3. terenów oznaczonych symbolami „1MN/U-mw, 3MN/U-mw, 3Um, 4Um, 1KDL, 6KDL, 7KDL, 8KDL, 2KDD, 1KDW i 2KDW, w zakresie, w jakim usytuowane są w odległości do $10 \mathrm{~m}$ od obszaru kolejowego stanowiącego granice terenu zamkniętego" [skarga s. 2]. Wojewódzki Sąd Administracyjny (WSA) w dniu 22 maja 2019 r. wydał wyrok, w którym:

1. „stwierdza nieważność zaskarżonej uchwały w części tekstowej i graficznej w zakresie dotyczącym obszarów o symbolach 7KDL, 2KK/D, 3KK/D, 1KK/D, 2KDD;

2. stwierdza nieważność zaskarżonej uchwały w części tekstowej i graficznej $\mathrm{w}$ odniesieniu do części obszarów o symbolach: 1MN/U-mw, 3MN/U-mw, 3Um, 4Um, 1KDL, $6 \mathrm{KDL}, 8 \mathrm{KDL}, 1 \mathrm{KDW}$ i 2KDW obejmujących tereny w odległości do $10 \mathrm{~m}$ od granicy terenu zamkniętego stanowiącej jednocześnie granicę obszaru kolejowego."

Burmistrz Miasta Mińsk Mazowiecki nie odwołał się od tego wyroku do Naczelnego Sądu Administracyjnego. Autor artykułu zastrzega, że nie był na sali sądowej w trakcie rozprawy, nie zna treści odpowiedzi Burmistrza Miasta Mińsk Mazowiecki na skargę organu nadzoru oraz przyczyn braku odwołania od wyroku. Opiera się na powszechnie dostępnych dokumentach, to znaczy na: uchwale Nr XLV.442.2018 Rady Miasta Mińsk Mazowiecki, ww. skardze organu nadzoru, wyroku WSA, omawianych powyżej pismach Ministrów oraz znajomości terenu, którego proces dotyczył.

Organ nadzoru oparł skargę, a Wojewódzki Sąd Administracyjny wyrok na założeniach, że:

1. obszar kolejowy oznacza to samo, co teren zamknięty ustalony przez ministra właściwego do spraw transportu (inaczej uważał ówczesny Minister Inwestycji i Rozwoju);

2. w planie miejscowym nie wolno dokonywać zmian przeznaczenia istniejącego obszaru kolejowego będącego jednocześnie terenem zamkniętym, ustalonym przez ministra właściwego do spraw transportu. 
Żeby wyjaśnić, na czym polega kontrowersyjność skargi i wyroku WSA, skupiono się na zagadnieniach zasadniczych, pomijając szczegóły (w tym aspekty, które nie dotyczą kolei). Ilustracje (w skali zbliżonej do 1:5000) w sposób schematyczny, pokazują mające związek $\mathrm{z}$ procesem:

1. obiekty istniejące na gruncie $\mathrm{w}$ dacie podjęcia zaskarżonej uchwały Nr XLV.442.2018 - (ryc. 1);

2. wybrane ustalenia planu miejscowego oraz tereny, na których na skutek wyroku WSA, przestała obowiązywać ww. uchwała - (ryc. 2).

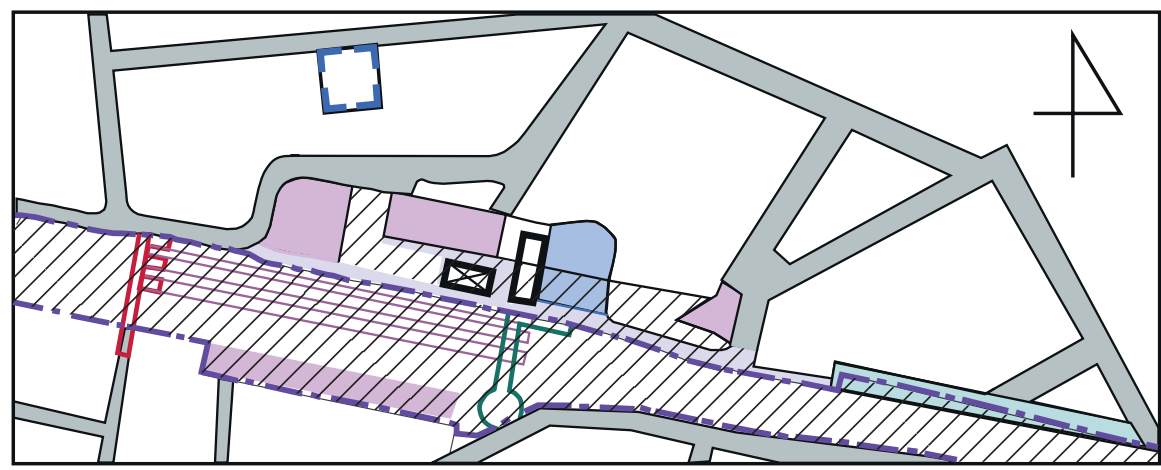

- - - granica terenu zamkniętego ustalonego przez ministra właściwego do spraw transportu

- granica terenu zamkniętego ustalonego przez ministra właściwego do spraw obrony narodowej

//, tereny kolejowe Tk [Załącznik nr 6 do rozp.eg]

układ uliczny

parkingi

budynek dworca autobusowego

teren dworca autobusowego

budynek dworca kolejowego [art. 4 pkt 8 a utk]

perony [pkt 6 Załącznika nr 1 do utk]

podziemne przejście dla pieszych, prowadzące na perony [pkt 4 i pkt 6 Załącznika nr 1 do utk], przejście służyło nie tylko podróżnym

nadziemne przejście dla pieszych, prowadzące na perony [pkt 4 i pkt 6 Załącznika nr 1 do utk], przejście służyło nie tylko podróżnym

droga ,dowozu i odwozu towarów do dróg publicznych” [pkt 7 Załącznika nr 1 do utk], droga pełniła również funkcję drogi publicznej, łącząc ulice Spółdzielczą i B. Limanowskiego

dojścia i dojazdy umożliwiające dotarcie do peronów pasażerom, ,pieszo lub pojazdem, z drogi publicznej lub dworca kolejowego" [pkt 6 Załącznika nr 1 do utk], dojścia i dojazdy obsługiwały także budynek i teren dworca autobusowego

Ryc. 1. Stan istniejący, w dacie podjęcia uchwały Nr XLV.442.2018 Rady Miasta Mińsk Mazowiecki w sprawie uchwalenia miejscowego palnu zagospodarowania przestrzennego miasta Mińsk Mazowiecki 


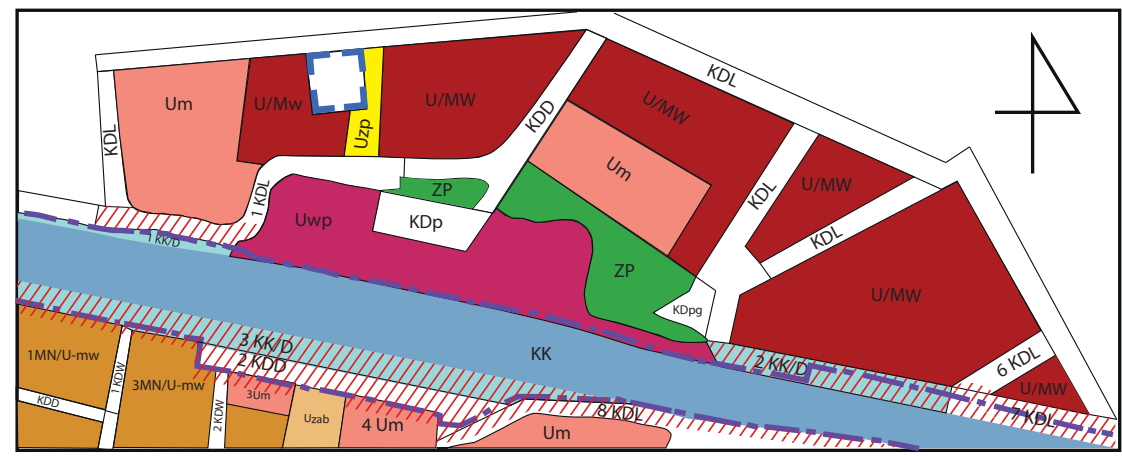

tereny, na których na podstawie wyroku WSA przestała obowiązywać uchwała Nr XLV.422.2018

- - - granica terenu zamkniętego ustalonego przez ministra właściwego do spraw transportu

- granica terenu zamkniętego ustalonego przez ministra właściwego do spraw obrony narodowej

tereny zabudowy mieszkaniowej jednorodzinnej i zabudowy usługowej z dopuszczeniem zabudowy mieszkaniowej wielorodzinnej (symbol MN/U-mw), w tym 1MN/U-mw i 3 MN/U-mw, których dotyczy wyrok WSA

tereny zabudowy usługowej i zabudowy mieszkaniowej wielorodzinnej (symbol U/MW)

tereny zabudowy usługowej z dopuszczeniem lokali mieszkalnych (symbol Um), w tym 3 Um i 4 Um, których dotyczy wyrok WSA

tereny zabudowy usługowej, obszar rozmieszczenia obiektów handlowych o powierzchni sprzedaży powyżej $2000 \mathrm{~m}^{2}$ (symbol Uwp)

teren zabudowy usługowej w otoczeniu zieleni (symbol Uzp)

teren zabudowy usługowej w otoczeniu zieleni wpisany do rejestru zabytków (symbol Uzab)

tereny zieleni (symbol ZP)

tereny dróg publicznych i dróg wewnętrznych (symbole KDL, KDD, KDW) oraz tereny placów i parkingów (symbole KDp i KDpg), w tym 1KDL, 6KDL, 7KDL, 8KDL, 2KDD, 1KDW, 2KDW, których dotyczy wyrok WSA

teren, na którym istnieją i mogą powstać obiekty wymienione w przepisie art. 4 pkt 8 ustawy o transposrcie kolejowym (symbol KK)

tereny budynków i budowli przeznaczonych do prowadzenia ruchu kolejowego i utrzymania linii kolejowej oraz do obsługi przewozu osób i rzeczy (symbol KK/D), w tym $1 \mathrm{KK} / \mathrm{D}, 2 \mathrm{KK} / \mathrm{D}, 3 \mathrm{KK} / \mathrm{D}$, których dotyczy wyrok WSA

Ryc. 2. Synteza ustaleń miejscowego planu zagospodarowania przestrzennego miasta Mińsk Mazowiecki, przyjętego uchwałą Nr XLV.442.2018 Rady Miasta Mińsk Mazowiecki Źródło: opracowanie własne

Cała uchwała Nr XLV.442.2018 - tekst planu i załącznik graficzny (rysunek planu), są dostępne w Internecie [Dziennik Urzędowy Województwa Mazowieckiego z 19 października 2018 r. poz. 9935]. 


\section{Stan istniejący}

Ustalenie granic obszaru kolejowego wymaga szczegółowych badań w celu wyznaczenia wszystkich działek ewidencyjnych, na których znajduje się droga kolejowa, budynki, budowle i urządzenia przeznaczone do zarządzania, eksploatacji i utrzymania linii kolejowej oraz przewozu osób i rzeczy [art. 4 pkt 8 utk], w tym urządzeń podziemnych i opatrzonych klauzulą tajności. Organ nadzoru nie wspomina o przeprowadzeniu takich badań. W uzasadnieniu wyroku WSA nie wskazano żadnych przepisów i dokumentów, na podstawie których stwierdzono, że działka ewidencyjna nr 2672/40 to obszar kolejowy. Napisano jedynie, że:

1. w granicach zaskarżonego miejscowego planu zagospodarowania przestrzennego „zlokalizowany jest obszar kolejowy, wchodzący w skład działki oznaczonej numerem ewidencyjnym 2672/40, stanowiący teren zamknięty"[WSA, s. 2];

2. „W obszarze kolejowym mogą być lokalizowane jedynie elementy infrastruktury kolejowej (...) nie zaś ogólnodostępne drogi publiczne" [WSA, s. 1 i 2];

3. na obszarze kolejowym brak „możliwości realizacji parkingów, obiektów małej architektury i ogrodzeń niezwiązanych z obsługą ruchu kolejowego i utrzymaniem linii kolejowej" [WSA, s. 2]. W dniu uchwalania zaskarżonego planu miejscowego (patrz ryc. 1):

1. na terenie zamkniętym (działka ewidencyjna nr 2672/40, własność Skarbu Państwa, w użytkowaniu wieczystym PKP SA) istniały:

- parking, wydzielony ogrodzeniem od terenów zajmowanych przez kolej i niezwiązany wyłącznie z obsługą ruchu kolejowego,

- $\quad$ podziemne i nadziemne przejścia dla pieszych, prowadzące na perony [pkt 4 i pkt 6 Załącznika nr 1 do utk]; ww. przejścia służyły nie tylko podróżnym, łączyły i łączą dwie części miasta przeciętego koleją;

2. na terenie zamkniętym i graniczącej z nim działce ewidencyjnej, istniała droga „dowozu i odwozu towarów do dróg publicznych" [pkt 7 Załącznika nr 1 do utk], obsługująca rampę do rozładunku węgla; ww. droga pełniła również funkcję drogi publicznej, łącząc ulice Spółdzielczą i B. Limanowskiego;

3. na działkach graniczących $\mathrm{z}$ terenem zamkniętym istniały:

- budynek dworca kolejowego,

- część nadziemnego przejścia dla pieszych - schody prowadzące na przejście,

- dojścia i dojazdy umożliwiające dotarcie do peronów pasażerom, „pieszo lub pojazdem, z drogi publicznej lub dworca kolejowego" [pkt 6 Załącznika nr 1 do utk]; ww. dojścia i dojazdy obsługiwały także budynek i teren dworca autobusowego;

4. w sąsiedztwie terenu zamkniętego istniały parkingi, które służyły mieszkańcom miasta, m.in., do zostawienia samochodów przed udaniem się w dalszą podróż pociągiem. Z powyższego wynika, że:

- $\quad$ teren zamknięty nie jest obszarem kolejowym, bo są na nim obiekty, które nie służą wyłącznie kolei, albo

- $\quad$ obszar kolejowy ma inny kształt niż teren zamknięty; obejmuje grunty z obiektami służącymi kolei, które nie wchodzą w skład terenu zamkniętego. 
To wszystko wystarcza, aby obalić twierdzenie, że teren zamknięty ustalony przez ministra właściwego do spraw transportu na działce ewidencyjnej nr 2672/40, to obszar kolejowy w rozumieniu ustawy o transporcie kolejowym. Autor zastrzega się, że nie dysponuje danymi pozwalającymi na szczegółową analizę obiektów znajdujących się pod ziemią.

\section{Uchwała Nr XLV.442.2018 nie wyznacza obszaru kolejowego}

W uzasadnieniu wyroku WSA napisano, że w skład obszaru kolejowego wchodzą tereny, lub ich części, oznaczone symbolami: KK, 1KK/D, 2KK/D, 3KK/D i 7KDL. „Przyjęte w zaskarżonej uchwale rozwiązania planistyczne dopuszczają w granicach obszaru kolejowego realizację dróg (ulic) i parkingów (...) niezwiązanych wyłącznie z obsługą ruchu kolejowego i utrzymaniem linii kolejowej." [WSA, s. 1].

Należy podkreślić, że zaskarżony plan miejscowy nie wyznacza obszaru kolejowego, a tym samym tereny oznaczone symbolami KK, 1KK/D, 2KK/D, 3KK/D i 7KDL nie wchodzą w jego skład.

Pozostaje bezspornym, że na obszarze objętym ww. planem istnieje droga kolejowa, a tym samym i linia kolejowa. Aby zagwarantować funkcjonowanie transportu kolejowego, plan ustala położenie i przeznaczenie terenu oznaczonego symbolem KK o nazwie „teren, na którym istnieją i mogą powstać obiekty wymienione w przepisie art. 4 pkt 8 ustawy (...) o transporcie kolejowym" [§31 uchwały], takie jak droga kolejowa, budynki, budowle i urządzenia przeznaczone do zarządzania, eksploatacji i utrzymania linii kolejowej oraz przewozu osób i rzeczy. Teren KK można traktować jako przyszły, potencjalny obszar kolejowy. Uchwała Nr XLV.442.2018 nie prowadzi do likwidacji ani jednego istniejącego toru kolejowego i tym samym linii kolejowej.

Tereny zamknięte wyznacza się ze względu na obronność i bezpieczeństwo państwa. Zaskarżony plan, zgodnie z wymaganiami ustawy o planowaniu i zagospodarowaniu przestrzennym, został uzgodniony z organami odpowiedzialnymi za obronność i bezpieczeństwo. Wymienione organy nie zakwestionowały przyjętego w planie miejscowym przeznaczenia terenu zamkniętego ustalonego przez ministra właściwego do spraw transportu.

\section{Uchwała Nr XLV.442.2018 - tereny o symbolach 1KK/D, 2KK/D, 3KK/D, 2KDD, 7KDL}

Fragmenty terenu zamkniętego, poza terenem KK, to grunty, które nie służyły i nie służą kolei, a znakomicie nadają się do usprawnienia układu drogowego miasta.

Tereny 1KK/D, 2KK/D i 3KK/D o nazwie „tereny budynków i budowli przeznaczonych do prowadzenia ruchu kolejowego i utrzymania linii kolejowej oraz do obsługi przewozu osób i rzeczy" [§ 32 uchwały] to grunty, na których plan pozwalał lokalizować:

1. "budynki i budowle przeznaczone do prowadzenia ruchu kolejowego i utrzymania linii kolejowej oraz do obsługi przewozu osób i rzeczy, o których mowa w przepisie art. 53 ust.4 ustawy (...) o transporcie kolejowym"; 
2. drogi (ulice) i parkingi oraz obiekty małej architektury i ogrodzenia nie związane wyłącznie z obsługą ruchu kolejowego i utrzymaniem linii kolejowej, lokalizowane w trybie przepisów dotyczących transportu kolejowego (...) oraz przepisu art. 9 ustawy (...) Prawo budowlane" [§ 32 ust. 1 uchwały].

Przy załażeniu, że nawet cały teren KK będzie w przyszłości traktowany jako obszar kolejowy, ustalenia dotyczące terenów 1KK/D, 2KK/D i 3KK/D nie naruszały przepisów ustawy o transporcie kolejowym, bo:

1. ww. budynki i budowle mogły być lokalizowane w odległości mniejszej niż $10 \mathrm{~m}$ od granicy obszaru kolejowego i mniejszej niż $20 \mathrm{~m}$ od osi skrajnego toru kolejowego (zgodnie z przepisie art. 53 ust. 4 utk);

2. drogi (ulice) i parkingi sąsiadujące $\mathrm{z}$ terenem KK mogłyby powstać, jeśli uzyska się stosowne odstępstwa od przepisów ustawy o transporcie kolejowym, na etapie występowania o pozwolenie na budowę.

Ustalenia dotyczące terenów 1KK/D, 2KK/D i 3KK/D to wyważenie interesów kolei i interesów miasta:

1. interes kolei zapewniało umożliwienie lokalizacji obiektów, które jej służą;

2. $\quad \mathrm{w}$ interesie miasta leżało powstanie nowych dróg publicznych i poszerzenie istniejącej ul. Kolejowej (1KDL) oraz to, że przyszły obszar kolejowy nie będzie większy niż teren KK, a tym samym nie zaistnieje konieczność zmian linii zabudowy na terenach przeznaczonych w planie pod budownictwo mieszkaniowe, usługi i produkcję.

Teren 7KDL [§ 26 uchwały] to teren istniejącej drogi, obsługującej m.in. rampę, na której sporadycznie rozładowuje się pociągi z węglem. Zaskarżony plan jedynie sankcjonował istnienie tej drogi ustalając, że jest to droga publiczna, bo de facto pełni taką funkcję.

Teren 2KDD [§ 27 uchwały], to istniejący parking, oddzielony ogrodzeniem od terenów wykorzystywanych przez kolej. Zaskarżony plan przeznaczył go na teren drogi publicznej. Droga leży w odległości większej niż 10 m od granicy terenu KK oraz równej 20 m od osi skrajnego toru kolejowego.

Jak już napisano - mienie PKP SA może być przekazane jednostkom samorządu terytorialnego na cele służące wykonywaniu zadań w dziedzinie transportu [art. 39 ust. 3 ukrPKP]. Takie zadania spełniają niewątpliwie drogi.

\section{Uchwała Nr XLV.442.2018 - tereny o symbolach 1MN/U-mw, 3MN/U-mw, 3Um, 4Um, 1KDL, 6KDL, 8KDL, 1KDW i $2 \mathrm{KDW}$}

Tereny 1MN/U-mw i 3MN/U-mw to „tereny zabudowy mieszkaniowej jednorodzinnej i zabudowy usługowej z dopuszczeniem zabudowy mieszkaniowej wielorodzinnej” [§ 15 uchwały], które sąsiadują z terenem 3KK/D. Tereny 3Um, 4Um to „tereny zabudowy usługowej z dopuszczeniem lokali mieszkalnych" [§ 18 uchwały], graniczące z terenem zamkniętym ustalonym przez ministra właściwego do spraw transportu. 
Nie ma żadnego przepisu, który nakazuje odsunięcie ww. terenów o 10 m od granicy powyższego terenu zamkniętego, a tym bardziej, kiedy jego fragmenty zostały w planie przeznaczone na tereny 3KK/D i 2KDD.

Należy podkreślić, że na obszarze objętym zaskarżonym planem istnieje również teren zamknięty ustalony przez ministra właściwego do spraw obrony narodowej. Ani organ nadzoru, ani WSA nie nakazały odsunięcia terenów przeznaczonych pod obiekty usługowe i mieszkaniowe od tego terenu.

Teren 1KDL to istniejąca ulica Kolejowa, teren 6KDL to istniejąca ulica Spółdzielcza, teren 8KDL to ciąg istniejących ulic: Mrozowskiej i gen. K. Sosnkowskiego, teren 1KDW to istniejąca ulica Widok, a teren 2KDW to istniejąca ulica Z. Mirosza. Powyższe ulice funkcjonują od kilkudziesięciu lat. Uchwała Nr XLV.442.2018 sankcjonowała istnienie tych ulic. Nawet, jeśli granica istniejącego terenu zamkniętego pokrywa się z granicą istniejącego i przyszłego obszaru kolejowego, to ww. ulice zostały wybudowane na podstawie stosownych pozwoleń. Wyrok WSA wydano 22 maja 2019 r. Jak do tej pory, żaden organ nadzoru budowlanego nie nakazał ich rozbiórki.

\section{Podsumowanie}

Od przedstawicieli tego samego rządu oczekuje się jednakowego podejścia do tych samych zagadnień. Gdyby organ nadzoru rozumował tak samo jak ówczesny Minister Inwestycji i Rozwoju, zapewne nie doszłoby do opisanego procesu.

Wyrok WSA zahamował kształtowanie układu ulicznego miasta Mińsk Mazowiecki. Spowodował chaos w ustaleniach zaskarżonego planu miejscowego - w tekście i na rysunku pojawiły się swego rodzaju białe plamy, które utrudniają korzystanie z tego aktu prawa, zwłaszcza osobom niezwiązanym zawodowo z planowaniem przestrzennym. Koszty procesu pokryli podatnicy. Istniejących ulic nikt, na szczęście, nie kazał likwidować. Szkoda, że $\mathrm{w}$ uzasadnieniu wyroku WSA nie napisano, na jaki cel powinny być przeznaczone tereny ww. ulic, żeby spełniały przepisy prawa.

Wyrok WSA pokazuje, że ustawa o planowaniu i zagospodarowaniu przestrzennym w zakresie dotyczącym sporządzania planów miejscowych dla terenów zamkniętych ustalonych przez ministra właściwego do spraw transportu jest inaczej rozumiana przez sporządzających te plany niż przez sędziów. Skoro plan miejscowy sporządza się dla ww. terenów zamkniętych oraz w planie miejscowym określa się obowiązkowo:

- $\quad$ przeznaczenie terenów [art. 15 ust. 2 pkt 1 upzp],

- $\quad$ zasady modernizacji, rozbudowy i budowy systemów komunikacji [art. 15 ust. 2 pkt 10 upzp].

To sporządzający plan ma prawo i obowiązek ustalenia przeznaczenia ww. terenów zamkniętych - może je zachować albo zmienić, a zmiana przeznaczenia nie jest uzależniona od uzyskania zgody żadnego organu, tak jak np. zmiana przeznaczenia gruntów leśnych na cele nieleśne. 
Wyrok WSA de facto neguje prawo do sporządzania planów miejscowych dla ww. terenów zamkniętych. Stanowi groźny precedens. Proces dotyczył naruszeń prawa, a nie np. naruszenia interesu prawnego Grupy PKP, poprzez przeznaczenie na drogi gruntów potrzebnych kolei. Skoro proces dotyczył wyłącznie naruszenia prawa, to można wyciągnąć z tego wniosek, że przeznaczanie części terenów zamkniętych ustalonych przez ministra właściwego do spraw transportu na inne cele, jest zawsze niezgodne z przepisami.

Dla funkcjonowania kolei, w ramach prac nad planami miejscowymi, potrzebne są zmiany prawa. Skoro ustawa o planowaniu i zagospodarowaniu przestrzennym jest w tym zakresie różnie rozumiana, to trzeba ją tak zredagować, aby nie budziła wątpliwości, przy czym nowelizacja tylko tej ustawy nie wystarczy.

Należy zacząć od wyznaczenia na mapach granic obszaru/ów kolejowych. Następnie trzeba nałożyć na siebie tereny kolejowe, tereny zamknięte ustalone przez ministra właściwego do spraw transportu oraz obszary kolejowe i porównać ich granice. Zapewne w wielu przypadkach będą się one pokrywać. Tam, gdzie tak nie będzie należy przeanalizować, jakie są tego przyczyny, być może wynikają jedynie z braku aktualnych danych w ewidencji gruntów i budynków. Rycina 1 pokazuje, że dworzec autobusowy leży na terenach kolejowych.

Tego typu badania pozwolą na ustalenie, czy w naszym systemie prawnym muszą istnieć aż trzy pojęcia określające tereny związane z koleją. Może wystarczyłyby tereny kolejowe, skoro są wyznaczone na mapach zasadniczych i w ewidencji gruntów i budynków. Wymagałoby to zapewne rozszerzenia definicji tego pojęcia o elementy wymienione $w$ definicjach zawartych w ustawie o transporcie kolejowym. Jak już napisano - podstawą planowania przestrzennego, wymiaru podatków i oznaczania nieruchomości w księgach wieczystych są dane pochodzące z ewidencji gruntów i budynków [art. 21 ust. 1 ugk].

Jeśli wymogi obronności i bezpieczeństwa wymuszają istnienie terenów zamkniętych ustalonych przez ministra właściwego do spraw transportu, to być może dałoby się je utożsamić z obszarem kolejowym, tak jak uważa WSA.

Jeżeli z jakichś względów muszą pozostać w naszym systemie prawnym ww. tereny zamknięte, tereny kolejowe i obszar kolejowy, to ten ostatni należy wyznaczyć na mapach: zasadniczych, odrębnych, albo jednych i drugich. Trzeba również zastanowić się, czy wokół obszaru kolejowego powinno się tworzyć swoisty bufor o szerokości $10 \mathrm{~m}$. Wprowadzanie ograniczeń, na gruntach należących do innych niż kolej podmiotów, wywołuje i będzie wywoływało protesty. Byłoby lepiej, aby obszar kolejowy, jeśli ma dalej pozostać w naszym systemie prawnym, stanowił własność Skarbu Państwa i miał wymiary pozwalające na zapewnienie bezpieczeństwa ruchu kolejowego w jego granicach. Nie są przedmiotem niniejszego artykułu rozważania na temat hałasu i drgań - uciążliwości dla terenów otaczających, spowodowanej ruchem pociągów.

Aby uniknąć procesów o naruszenie interesu prawnego spółek Grupy PKP projekty planów miejscowych powinny być, w trakcie ich sporządzania, uzgadniane $\mathrm{z}$ organem odpowiedzialnym za interesy kolei. Należy wskazać taki organ w ustawie o planowaniu i zagospodarowaniu przestrzennym oraz w przepisach odrębnych dotyczących transportu kolejowego. Może nim być np. Prezes Urzędu Transportu Kolejowego. 
Postulowane zmiany prawa powinny ograniczyć procesy, dotyczące stwierdzania nieważności miejscowych planów zagospodarowania przestrzennego. Ułatwią sporządzanie tych planów, a to umożliwi kształtowanie przestrzeni miast i wsi na styku z koleją w sposób, który nie kreuje konfliktów.

\section{Literatura}

Chudzikiewicz A. (red.), 2012, Leksykon terminów kolejowych, Kolejowa Oficyna Wydawnicza, Warszawa.

Ciechański A., 2017, Państwo wobec kolei żelaznych w Polsce [w:] M. Kapias, D. Keller (red.), Inicjator versus likwidator. Zmiana roli samorząów w kształtowaniu sieci kolei waskotorowych w Polsce na tle innych rozwiazań europejskich, Muzeum w Rybniku, Rybnik, s. 71-92.

Ciechański A., 2018, Warszawskiekolejedojazdowe-potencjał utracony? CzasopismoGeograficzne, $89,1-2$, s. $17-42$.

Ciechański A., Taylor Z., 2017, Deregulacja i przekształcenia własnościowe przedsiębiorstw transportu lądowego w Polsce na tle polityki spójności UE, Prace Geograficzne, 257, Instytut Geografii i Przestrzennego Zagospodarowania im. Stanisława Leszczyckiego PAN, Warszawa.

Janczewski Henryk, 1971, Warszawa. Geneza i rozwój inżynierii miejskiej, Arkady, Warszawa.

Liszaj T. (tekst), Kastelik M.M. (red. prowadzący), 2011, Zabytkowe dworce w Polsce, Wydawnictwo Dragon, Bielsko-Biała.

Niewiadomski Z. (red.), 2019, Planowanie i zagospodarowanie przestrzenne. Komentarz, wyd. 11, Seria: Komentarze Becka, Warszawa.

Taylor Z., 2007, Rozwój i regres sieci kolejowej w Polsce, Monografie, 7, Instytut Geografii i Przestrzennego Zagospodarowania im. Stanisława Leszczyckiego PAN, Warszawa.

\section{Źródła prawa}

\section{Ustawy}

Ustawa z dnia 17 maja 1989 r. Prawo geodezyjne i kartograficzne, tj. z dnia 28 stycznia 2020 r. (Dz.U. z 2020 r. poz. 276 z późn. zm.), w skrócie ugk.

Ustawa z dnia 7 lipca 1994 r. Prawo budowlane, tj. z dnia 21 maja 2019 r. (Dz.U. z 2019 r. poz. 1186 z późn. zm.), w skrócie uPb.

Ustawa z dnia 21 sierpnia 1997 r. o gospodarce nieruchomościami, tj. z dnia 22 listopada 2019 r. (Dz.U. z 2020 r. poz. 65 z późn. zm.), w skrócie ugn. 
Ustawa z dnia 8 września 2000 r. o komercjalizacji i restrukturyzacji przedsiębiorstwa państwowego „Polskie Koleje Państwowe”, tj. z dnia 28 stycznia 2020 r. (Dz.U. z 2020 r. poz. 292), w skrócie ukrPKP.

Ustawa z dnia 27 marca 2003 r. o planowaniu i zagospodarowaniu przestrzennym, tj. z dnia 6 lutego 2020 r. (Dz.U. z 2020 r. poz. 293), w skrócie upzp.

Ustawa z dnia 28 marca 2003 r. o transporcie kolejowym, tj. z dnia 15 marca 2019 r. (Dz.U. z 2019 r. poz. 710, z późn. zm.), w skrócie utk.

\section{Rozporządzenia}

Rozporządzenie z dnia 29 marca 2001 r. Ministra Rozwoju Regionalnego i Budownictwa w sprawie ewidencji gruntów i budynków, tj. z dnia 3 stycznia 2019 r. (Dz.U. z 2019 r. poz. 393), w skrócie rozp. eg.

Rozporządzenie Ministra Infrastruktury z dnia 26 sierpnia 2003 r. w sprawie wymaganego zakresu projektu miejscowego planu zagospodarowania przestrzennego (Dz.U. nr 164, poz. 1587), w skrócie rozp. mpzp.

\section{Akty prawa miejscowego}

Uchwała Nr XLV.442.2018 Rady Miasta Mińsk Mazowiecki z dnia 15 października 2018 r. w sprawie uchwalenia miejscowego planu zagospodarowania przestrzennego miasta Mińsk Mazowiecki (Dz.Urz. Woj. Mazowieckiego z 19 października 2018 r. poz. 9935), w skrócie uchwała Nr XLV.442.2018, lub uchwała.

\section{Dokumenty}

Skarga Wojewody Mazowieckiego, z dnia 8 stycznia 2019 r. na uchwałę Nr XLV.442.2018 Rady Miasta Mińsk Mazowiecki z dnia 15 października 2018 r. w sprawie uchwalenia miejscowego planu zagospodarowania przestrzennego miasta Mińsk Mazowiecki, w skrócie skarga.

Interpelacja nr 29420 do Ministra Infrastruktury oraz do Ministra Inwestycji i Rozwoju w sprawie określenia organu upoważnionego do wydawania pozwoleń na budowę w bliskości torów kolejowych oraz precyzyjnego określenia odległości obiektu od granicy obszaru kolejowego. Zgłaszający: Małgorzata Pępek. Data wpływu: 14. 02. 2019, w skrócie interpelacja nr 29420.

Minister Inwestycji i Rozwoju, data: 08.03.2019, znak sprawy: DAB-II.053.8.2019.JJ. Dotyczy: odpowiedzi na interpelację nr 29420 Poseł Małgorzaty Pępek, pismo podpisał z upoważnienia ówczesnego Ministra Inwestycji i Rozwoju Pan Artur Soboń - Sekretarz Stanu, w skrócie MIR. 
Minister Infrastruktury, data: 11.03.2019, znak sprawy: DTK-3.054.1.2019. Dotyczy: odpowiedzi na interpelację nr 29420 Poseł Małgorzaty Pępek, pismo podpisał z upoważnienia Ministra Infrastruktury Pan Andrzej Bittel - Podsekretarz Stanu, w skrócie MI.

Wojewódzki Sąd Administracyjny w Warszawie, wyrok z dnia 22 maja 2019 r., sygnatura akt IV SA/Wa 349/19, w skrócie WSA.

\section{Railways in a local spatial development plan}

\section{ABSTRACT}

As a result of the chaos in the legislation and its interpretation, it is difficult to draw up local spatial development plans that apply to:

1. conversion of land owned by the railway to other purposes unnecessary for its operation, while maintaining existing railway lines;

2. areas adjacent to the railway.

Using the example of a selected local spatial development plan and the verdict of the Voivodship Administrative Court it has been shown to what absurdities the existing legal system leads to. Using three notions for railway-related land is one of the basic problems. These are:

1. Railway land, within the meaning of the regulation on the registration of land and buildings;

2. Closed areas established by the minister in charge of transport, referred to in the Spatial Planning and Development Act;

3. Railway area, within the meaning of the Railway Transport Act.

Modifications to the regulations have been suggested, including the elimination of at least one of the above-mentioned notions. The proposed amendments to the law should facilitate the drawing up of local spatial development plans. This will make it possible to shape the urban and rural areas adjacent to the railways in a way that does not generate conflicts.

Key words: railway area, railway land, closed areas, local spatial development plan

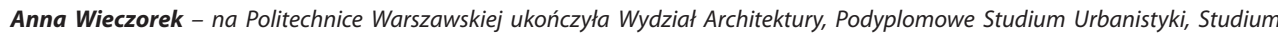
Doskonalenia Pedagogicznego oraz uzyskała dyplom doktora nauk technicznych. Posiada uprawnienia do projektowania w planowaniu przestrzennym oraz uprawnienia do pełnienia samodzielnych funkcji technicznych w budownictwie. Specjalizuje się w wykonywaniu projektów miejscowych planów zagospodarowania przestrzennego (główny projektant ponad 30 uchwalonych projektów planów miejscowych) oraz projektów studiów uwarunkowań i kierunków zagospodarowania przestrzennego gmin (główny projektant 5 uchwalonych stdiów). Ma doświadczenie w pracy ze studentami - na Politechnice Warszawskiej i w Wyższej Szkole Przedsiębiorczości i Administracji w Lublinie. Należy do Mazowieckiej Okręgowej lzby Architektów z siedzibq̨ w Warszawie oraz Pan-Europejskiej Federacji Ochrony Zabytków - Europa Nostra z siedzibq w Holandii.

Anna Wieczorek - graduated from Warsaw University of Technology - Faculty of Architecture, Postgraduate Town Planning Studies, Pedagogical study, PhD in technical science. She holds professional permits for spatial planning and is authorized to perform independent technical functions in construction. She specializes in the execution of local spatial development plans (the main designer of more than 30 approved local development plans) and of the studies of conditions and directions of the spatial development of municipalities (main designer of 5 approved studies). She has experience in working with students - at the Warsaw University of Technology and the University College of Enterprise and Administration in Lublin. She belongs to Warsaw-based Masovian Chamber of Architects and the Pan-European Federation for Cultural Heritage, Europa Nostra based in the Netherlands.
} 